\title{
SCREENING OF SELECTED FOREST TREE SPECIES \\ OF SRI LANKA FOR THEIR RESPONSE TO INCREASING ATMOSPHERIC CARBON DIOXIDE
}

\author{
W A J M De Costa, A T Ekanayake, K G R Chinthaka and P Surenthran \\ Department of Crop Science, Faculty of Agriculture, \\ University of Peradeniya
}

Investigating the effects of increasing atmospheric $\mathrm{CO}_{2}$ on forest tree species is important as forests play a major role in maintaining the ecological balance of an ecosystem. The objective of this study was to determine the response of photosynthesis, and it related physiological parameters, Growth and morphological parameters of selected forest tree species such as Teak (Tectona grandis), Jak (Artocarpus heterophyllus), Satinwood (Chloroxylon swietenia), and two varieties of Mahogany (Swietenia macrophylla and Swietenia mahogany) to elevated $\mathrm{CO}_{2}$.

The experiment was carried out at the Rice Research and Development Institute (RRDI), Batalagoda, Ibbagamuwa, from October 2002 to February 2003. Three experimental treatments were defined as elevated $\mathrm{CO}_{2}$ (i.e., $570 \mathrm{ppm}$ ) in open top chambers, ambient $\mathrm{CO}_{2}$ (i.e., $370 \mathrm{ppm}$ ) in open top chambers and ambient $\mathrm{CO}_{2}$ (i.e., $370 \mathrm{ppm}$ ) under open field conditions. The experiment was conducted over a period of 161 days.

The total dry weight was higher under elevated $\mathrm{CO}_{2}$ as compared to ambient $\mathrm{CO}_{2}$ in all species except Chloroxylon swietenia. The response was highest in Swietenia macrophylla and the highest mean total dry weight was in the elevated $\mathrm{CO}_{2}$ treatment. The mean root dry weight, mean leaf dry weight and mean stem dry weight were significantly higher under elevated $\mathrm{CO}_{2}$ as compared to the ambient. The height increment during the experimental period was highest in Chloroxylon swietenia under elevated $\mathrm{CO}_{2}$. The girth increment during this period was highest in Swietenia macrophylla and it was observed in the elevated $\mathrm{CO}_{2}$ treatment. When averaged across all species, the mean relative growth rates and absolute growth rates were higher under elevated $\mathrm{CO}_{2}$ than under ambient. When individual species were considered, only Chloroxylon swietenia showed a slight decrease in absolute and relative growth rates under elevated $\mathrm{CO}_{2}$ while the others shows an increase. Net photosynthetic rate $(\mathrm{Pn})$ was higher in the elevated $\mathrm{CO}_{2}$ treatment in Artocarpus heterophyllus, Swietenia mahogany and Tectona grandis. But a slight decrease of Pn was observed in Swietenia macrophylla under elevated $\mathrm{CO}_{2}$ in comparison to ambient $\mathrm{CO}_{2}$. Leaf water potential was higher in all five species under elevated $\mathrm{CO}_{2}$ and the highest response to elevated $\mathrm{CO}_{2}$ was observed in Chloroxylon swietenia. The stomatal diffusive resistance was highest in Tectona grandis and the value was $16.86 \mathrm{~s} \mathrm{~cm}^{-1}$. The lowest was observed in Chloroxylon swietenia and the value was $2.87 \mathrm{~s} \mathrm{~cm}^{-1}$. The lowest diffusive resistance was observed in the elevated $\mathrm{CO}_{2}$ treatment. The transpiration rate was highest in Chloroxylon swietenia and the value was $12.71 \mu \mathrm{g} \mathrm{cm}^{-2} \mathrm{~s}^{-1}$. The lowest was observed in Artocarpus heterophyllus and there was no significant difference among the three treatments. The mean leaf temperature was highest in Artocarpus heterophyllus and the lowest leaf temperature was found in Chloroxylon swietenia.

Based on the above results, it can be concluded that elevated $\mathrm{CO}_{2}$ increases growth of a majority of tree species tested. This could have favourable implications for both natural and plantation forestry in Sri Lanka. Results of the present study showed that the capacity of forests for carbon sequestration would be higher in a future climate with higher atmospheric $\mathrm{CO}_{2}$ levels.

Proceedings of the Ninth Annual Forestry and Environment Symposium 2003 of the Department of Forestry and Environmental Science, University of Sri Jayewardenepura, Sri Lanka 